\title{
Augmented Production of Heparin-binding Mitogenic Proteins by Preadipocytes from Massively Obese Persons
}

\author{
Krystyna Teichert-Kuliszewska, Bradford S. Hamilton, Mervyn Deitel, ${ }^{\star}$ and Daniel A. K. Roncari \\ Institute of Medical Science and Departments of Medicine, Sunnybrook Health Science Centre and University of Toronto, \\ Toronto, Ontario M4N 3M5; and *Departments of Surgery and Nutritional Sciences, \\ St Joseph's Health Centre and University of Toronto, Toronto, Ontario M6R 1B5, Canada
}

\begin{abstract}
Basic fibroblast growth factor (bFGF) stimulates the replication of preadipocytes and inhibits their differentiation. In this study we explored whether the same or related polypeptides were produced locally and acted by paracrine / autocrine mechanisms in adipose tissue. Omental preadipocytes from 7 lean and 10 massively obese ( $>170 \%$ reference) subjects were grown to confluence in subculture. Total RNA was hybridized with a synthetic deoxynucleotide for human bFGF. In the case of all cell strains, there was expression of two major bFGF transcripts, 7.0 and $3.7 \mathrm{~kb}$. Although there was considerable variation in the degree of expression, preadipocytes from massively obese subjects revealed much greater expression than did cells from the lean $(P<0.001)$. In studies of conditioned media prepared with preadipocytes, the presence of proteins belonging to the heparin-binding (fibroblast) growth factor family was indicated by Western blot analysis, for a $66-\mathrm{kD}$ protein with anti-(1-24) bFGF, and for a 32-kD protein with anti-(4063) bFGF antibodies. The relative quantity of the $66-\mathrm{kD}$ protein correlated with body mass index at $r=0.72$. bFGF-related proteins probably function normally to maintain an appropriate complement of adipocyte precursors. The augmented expression of heparin-binding growth factors in preadipocytes from some massively obese people probably contributes to the excessive cellularity of their fat depots. (J. Clin. Invest. 1992. 90:1226-1231.) Key words: autocrine/paracrine • fibroblast growth factors $\bullet$ hyperplasia
\end{abstract}

\section{Introduction}

The mechanisms responsible for normal development and maintenance of the cellular composition of adipose tissue are only known to a limited degree $(1,2)$. While adipose cells (preadipocyte and adipocyte) and endothelial cells must undoubtedly interact, the details require clarification (3). Further, the following two aspects are of both fundamental and clinical significance: first, the mechanisms responsible for regional, cellular, and metabolic variations between adipose depots, as well as the pathologic extension of these disparities resulting in "abdominal obesity," and secondly, the factors

Address reprint requests to Dr. Roncari, Sunnybrook Health Science Centre, 2075 Bayview Avenue, North York, Ontario M4N 3M5, Canada.

Received for publication 14 October 1991 and in revised form 4 May 1992.

J. Clin. Invest.

(C) The American Society for Clinical Investigation, Inc.

$0021-9738 / 92 / 10 / 1226 / 06 \$ 2.00$

Volume 90, October 1992, 1226-1231 leading to the adipocyte hyperplasia characteristic of massive obesity.

Basic fibroblast growth factor (bFGF), ${ }^{1}$ and probably other members of the heparin-binding (fibroblast) growth factor family contribute to the induction of embryonic mesoderm and are mitogenic for various mesenchymal cells $(4,5)$. The well-characterized $16-18-\mathrm{kD}$ bFGF, as well as related higher molecular mass polypeptides from bovine pituitaries, also stimulate the replication of cultured preadipocytes $(6,7)$. Because bFGF also inhibits adipose differentiation, it may well contribute significantly to the size of the preadipocyte pools in fat tissue ( 8 , 9 ). In addition to influencing cellular content, the potent angiogenic effect of bFGF is probably critical during the development of various tissues, including adipose depots (10).

Recent studies indicate that $\mathrm{bFGF}$ and related polypeptides are produced in a variety of tissues, where they may have a paracrine/autocrine function. Indeed, this report will describe that cultured human preadipocytes themselves express mRNA encoding for a protein (s) related to bFGF and produce such a protein(s). In addition, preadipocytes from some massively obese subjects reveal much greater expression.

\section{Methods}

Culture of preadipocytes. Preadipocytes were isolated and grown from human and rat adipose tissue according to previously reported methods (11-15). Human omental adipose tissue was obtained, after obtaining informed consent, from subjects undergoing elective abdominal surgery. The body mass index $\left(\mathrm{BMI}, \mathrm{kg} / \mathrm{m}^{2}\right)$ was used as an indicator of degree of obesity. Subjects were considered massively obese when their BMI exceeded $37 \mathrm{~kg} / \mathrm{m}^{2}$. Cells were grown in complete $\alpha$-MEM supplemented with $15 \%$ FBS (Gibco Laboratories, Grand Island, NY), $15 \mathrm{mM}$ Hepes, and antibiotics.

Preparation of conditioned medium. Preparation of conditioned medium from human omental preadipocytes was as described by Lau et al. (16). Briefly, preadipocytes (in the second to sixth passages) were grown to confluence in 100-mm (Corning Glass Works, Corning, NY) or 150-mm (Falcon Plastics, Cockeysville, MD) diam culture dishes. At confluence, the cells were washed four times with HBSS, and the cells were incubated with $\alpha$-MEM devoid of nucleosides, FBS, and antibiotics for $24 \mathrm{~h}$, at a concentration of $200 \mu \mathrm{l}$ of medium for each square centimeter of growing area, i.e., $10 \mathrm{ml} / 100-\mathrm{mm}$ plate. The overlying $\alpha$-MEM was designated "conditioned" medium. After detachment of cells with trypsin, the number of preadipocytes from which the conditioned medium was derived was determined with a $\mathrm{ZM}$ counter (Coulter Electronics Inc., Hialeah, FL) or hemocytometer.

The conditioned medium was spun at $40,000 \mathrm{~g}$ in a centrifuge (model RC5B, DuPont-Sorvall, Newtown, CT) and decanted. The supernatant fluid was concentrated by ultrafiltration. Filters had nominal molecular mass cutoff of $10 \mathrm{kD}$. Protein concentration was determined

1. Abbreviations used in this paper: bFGF, basic fibroblast growth factor; BMI, body mass index. 
with a protein assay kit (Bio-Rad Laboratories, Richmond, CA), which was calibrated with gamma globulin (Bio-Rad Laboratories) (17).

Assay of mitogenic activity. Cell replication was determined by quantifying the incorporation of $\left[\right.$ methyl $\left.-{ }^{3} \mathrm{H}\right]$ thymidine into trichloroacetic acid-insoluble macromolecules (DNA) of rat perirenal preadipocytes (11-13). Rat perirenal preadipocytes were chosen because virtually all these cells could be induced to undergo adipose differentiation in the first and second subcultures, thus confirming their preadipose nature $(9)$.

The preadipocytes in the second or third subculture were plated on 24-well plates at a density of 10,000 cells per well in $0.5 \mathrm{ml}$ of $\alpha$-MEM supplemented with $10 \% \mathrm{FBS}$ and antibiotics, for $\sim 24 \mathrm{~h}$ at $37^{\circ} \mathrm{C}$ with $5 \% \mathrm{CO}_{2}$. Subsequently, the cells were washed three times with HBSS and the medium changed to $\alpha$-MEM without nucleosides and $0.5 \%$ FBS to place the cells in serum starved quiescence. Putative mitogens and controls were then added to the cells after $24 \mathrm{~h}$. The positive control was 5\% FBS; the negative control was MEM without nucleosides. Controls were included in all experiments. After an additional $24 \mathrm{~h}$, [ $m e t h y l-{ }^{3} \mathrm{H}$ ] thymidine (Amersham Canada Inc., Oakville, ON; 37 $\mathrm{kBq}$ per well; sp act $1.85 \mathrm{TBq} / \mathrm{mmol}$ ) was added. Incorporation was allowed to proceed for $24 \mathrm{~h}$ after which the cells were washed four times with $\mathrm{HBSS}$ and harvested with $0.5 \mathrm{mg} / \mathrm{ml}$ trypsin- $2 \mathrm{mM} \mathrm{Na}_{2}$ EDTA in $\mathrm{Na}_{2}$-citrate- $\mathrm{KCl}$ solution. The cell suspensions were placed onto glass microfiber filters (GF/C, Whatman, Inc., Clifton, $\mathrm{NJ}$ ) with a sampling manifold. The amount of radioactivity retained on the filters after washing with $5 \%$ trichloroacetic acid was determined in a $\beta$ counter (model LS6000IC Liquid Scintillation System, Beckman Instruments Inc., Mississauga, $\mathrm{ON}$ ).

Periodically, cell replication was also assessed by direct enumeration with a Coulter Counter or with a hemocytometer. All determinations were conducted in triplicate or quadruplicate.

Responsiveness and sensitivity to $b F G F$. Human preadipocytes from lean and obese subjects were tested for their responsiveness and sensitivity to recombinant human bFGF (Bioproducts for Science Inc., Indianapolis, IN). Human omental preadipocytes from lean and obese subjects were seeded on 96-well plates at a concentration 10,000 cells per well. The cells were induced into quiescence, then bFGF was added after $24 \mathrm{~h}$, and then [ methyl $-{ }^{3} \mathrm{H}$ ] thymidine was added after $72 \mathrm{~h}$. The next day cells were washed twice with HBSS, trypsinized, and collected on glass filters (Printed Filtermat A, Pharmacia [Canada] Inc., Baie d'Urfé, QU) with a model 530 Titertek cell harvester (Flow Laboratories, Irvine, Scotland). The filters were dried, then counted in a liquid scintillation counter (model 1205 Betaplate, Wallac; Pharmacia [Canada] Inc.) with Cytoscint EC* (ICN Biomedicals Canada Ltd., St. Laurent, QU). All determinations were conducted in triplicate.

Heparin-agarose affinity chromatography. Samples were applied to heparin-agarose columns (Affi-Gel heparin gel; Bio-Rad Laboratories) that had been equilibrated with $10 \mathrm{mM}$ sodium phosphate buffer $(\mathrm{pH}$ 7.4 ) containing $0.15 \mathrm{M} \mathrm{NaCl}$. The column was washed with the same buffer solution, and then eluted with $10 \mathrm{mM}$ sodium phosphate buffer ( $\mathrm{pH} 7.4$ ), containing, sequentially, $0.6 \mathrm{M} \mathrm{NaCl}, 1.1 \mathrm{M} \mathrm{NaCl}, 2.0 \mathrm{M}$ $\mathrm{NaCl}$, and $3.0 \mathrm{M} \mathrm{NaCl}$ at a flow rate of $10-20 \mathrm{ml} / \mathrm{h}^{1}$. Fractions were collected, pooled, concentrated, and assayed for their ability to stimulate replication of rat perirenal preadipocytes. Fractions containing heparin-binding growth factors were detected using standard ELISA procedures with anti-(40-63)bFGF antibodies and the chromogen 2,2'-azino-di-[3-ethylbenzthiazolin-6-sulfonic acid] (Bio-Rad Laboratories).

SDS-PAGE and Western immunoblotting. Slab gels (12.5\%) were run in the buffer system of Laemmli (18) on a Mini-Protean II system (BioRad Laboratories). Molecular mass standards (14-97.4 kD, BioRad Laboratories) as well as recombinant human bFGF were included in the analysis. Proteins were detected by silver staining (BioRad Laboratories) or transferred onto $0.45 \mu \mathrm{m}$ Hybond-ECL nitrocellulose membranes (Amersham Canada Inc.) by electrophoretic transfer with a Tris-glycine-methanol buffer $(25 \mathrm{mM}$ Tris, $192 \mathrm{mM}$ glycine, $20 \%$ methanol, $\mathrm{pH} 8.4-8.6$ ). Nonspecific protein-binding sites on the nitrocellulose were blocked with 5\% skim milk in PBS-0.05\% Tween 20. The nitrocellulose membranes were then incubated in PBS$0.05 \%$ Tween 20 at $20^{\circ} \mathrm{C}$ for $1 \mathrm{~h}$ with anti-bFGF sera or antibodies: 1/1,000 dilution of anti-(1-24)bFGF serum (kindly donated by Dr. A. Baird, Salk Institute, San Diego, CA), or $5 \mu \mathrm{g} / \mathrm{ml}$ anti-(4063) bFGF antibodies (Oncogene Science, Inc., Manhasset, NY). The membranes were washed $3 \times 10 \mathrm{~min}$, then incubated for $1 \mathrm{~h}$ with a $1 / 10,000$ dilution of a goat anti-rabbit $\operatorname{lgG}(\mathrm{H}+\mathrm{L})$ horseradish peroxidase conjugate (Bio-Rad Laboratories) at $25^{\circ} \mathrm{C}$ and rinsed again. Antigen-antibody complexes were detected with an enhanced chemiluminescent Western blotting system (Amersham Corp.).

RNA isolation and Northern analysis. Total cellular RNA was isolated using the method of Chomczynski and Sacchi (19). Where appropriate, all solutions and containers were treated with diethyl pyrocarbonate and/or autoclaved to prevent RNA degradation. Briefly, the confluent cells were washed three times with ice-cold PBS. Denaturing solution $\left(\sim 1 \mathrm{ml} / 10^{7}\right.$ cells, $4 \mathrm{M}$ guanidinium thiocyanate, $25 \mathrm{mM}$ sodium citrate, $0.5 \% N$-lauryl-sarcosine, $0.1 \mathrm{M} 2$-mercaptoethanol, $\mathrm{pH}$ 7.0 ) was then added, and the cell suspension was harvested by scraping and transferred to sterile $15-\mathrm{ml}$ polypropylene tubes. Sequentially, mixing after each addition, $(a) 2 \mathrm{M}$ sodium acetate, $\mathrm{pH} 4.0,(b)$ watersaturated phenol, and $(c)$ chloroform-isoamyl alcohol $(49: 1)$ were added to the $(d)$ denaturing solution $(0.1: 1: 0.2: 1 ; \mathrm{vol} / \mathrm{vol} / \mathrm{vol} / \mathrm{vol})$. The final suspension was shaken vigorously for $10 \mathrm{~s}$, then incubated for $15 \mathrm{~min}$ at $0-4^{\circ} \mathrm{C}$. Samples were centrifuged at $10,000 \mathrm{~g}$ for $20 \mathrm{~min}$ at $4^{\circ} \mathrm{C}$. After centrifugation, the aqueous phase was transferred to fresh tubes and mixed with $1 \mathrm{vol}$ of isopropanol, and the tubes were then incubated at $-20^{\circ} \mathrm{C}$ for at least $1 \mathrm{~h}$ (usually overnight) to precipitate the RNA. Sedimentation at $10,000 \mathrm{~g}$ for $20 \mathrm{~min}$ was performed again, the RNA pellet was resuspended in $0.6 \mathrm{ml}$ of the denaturing solution, and precipitated with 1 vol of isopropanol at $-20^{\circ} \mathrm{C}$ for $1 \mathrm{~h}$. The resulting RNA pellet was resuspended in $70 \%$ ethanol, sedimented, dried in a vacuum, and dissolved in 50-200 $\mu$ l diethyl pyrocarbonate-treated water at $65^{\circ} \mathrm{C}$ for $10 \mathrm{~min}$. For isolation of RNA from adipocytes and whole adipose tissue, floating lipid was removed from the solution D homogenate after centrifugation $(10,000 \mathrm{~g})$ and the aqueous phase was treated, as detailed above, as the cultured cell suspension. Quantity and purity of the RNA was estimated at $A_{260}$ and $A_{280}$ using a spectrophotometer (model DU70, Beckman Instruments, Inc., Palo Alto, CA).

$40 \mu \mathrm{g}$ of total RNA from each subject was treated with $2.2 \mathrm{M}$ formaldehyde in $50 \%$ formamide, $200 \mathrm{mM}$ Hepes, $\mathrm{pH} \mathrm{7}$, at $65^{\circ} \mathrm{C}$ for $15 \mathrm{~min}$ and RNA was separated by electrophoresis in $1 \%$ agarose $/ 2.2 \mathrm{M}$ formaldehyde gels at $30 \mathrm{~V}$ for $16 \mathrm{~h}$ with recirculating $20 \mathrm{mM}$ sodium phosphate buffer ( $\mathrm{pH} 7.0$ ) and transferred to Gene Screen Plus nylon membranes (NEN Research Products, Boston, MA) following the method suggested by the manufacturer. The bFGF probe was a 40 -base singlestranded synthetic oligonucleotide ( $42.5 \%$ GC content) obtained from Oncogene Science Inc. ( $2.5 \mathrm{pmol}$ or $32.5 \mathrm{ng}$ ). The oligonucleotide probe was 5 -end labeled with $\left[\gamma^{32} \mathrm{P}\right] \mathrm{ATP}$ using $\mathrm{T}_{4}$ polynucleotide kinase to high specific activity $\left(3.2-6.4 \times 10^{6} \mathrm{cpm} / \mathrm{pmol}\right.$ or $2.5-4.9$ $\times 10^{8} \mathrm{cpm} / \mu \mathrm{g}$ ) and purified on a Sephadex G25 column (Pharmacia [Canada]).

Hybridization was conducted for $24 \mathrm{~h}$ at $65^{\circ} \mathrm{C}$ in hybridization buffer ( $1 \mathrm{M} \mathrm{NaCl}, 50 \mathrm{mM}$ Tris- $\mathrm{HCl}$ [ $\mathrm{pH} 7.5$ ], $10 \%$ dextran sulfate, $1 \%$ SDS, $100 \mu \mathrm{g} / \mathrm{ml}$ denatured salmon sperm DNA, and probe $5 \times 10^{6}$ $\mathrm{cpm} / \mathrm{ml}$ ). This buffer provided an optimum signal-to-noise ratio. After hybridization, the filters were washed under conditions of high stringency in $2 \times \mathrm{SSC}\left(0.3 \mathrm{M} \mathrm{NaCl}, 0.03 \mathrm{M} \mathrm{Na}_{3}\right.$ citrate $\left.\cdot 2 \mathrm{H}_{2} \mathrm{O}, \mathrm{pH} 7.0\right)$, containing $0.1 \%$ SDS according to the manufacturer's instructions. Signals were detected at $-70^{\circ} \mathrm{C}$ with intensifying screens on X-OMAT AR film (Eastman Kodak Co., Rochester, NY). Results were quantified by scanning densitometry with a video densitometer (model 620, Bio-Rad Laboratories). Densitometric data were standardized against the level of $28 \mathrm{~S}$ ribosomal RNA expression in each sample.

Statistical analyses. Statistical analyses were carried out using regression analysis and the $t$ test. Tests were performed with StatWorks (Version 1.2; Cricket Software Inc., Philadelphia, PA) on a Macintosh IIx computer. 


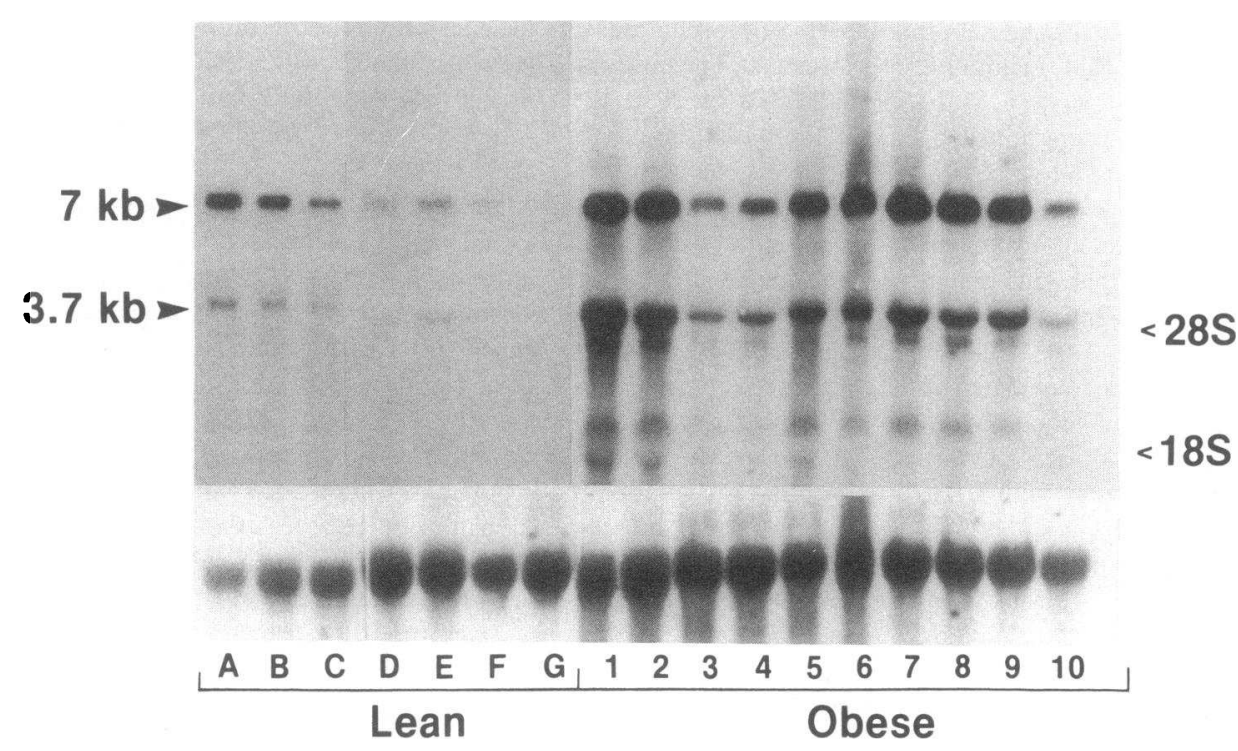

Figure 1. Northern blot analysis of RNA derived from cultured preadipocytes from lean and massively obese persons. Total RNA from cells grown in subculture ( $40 \mu \mathrm{g}$ per lane) was hybridized with a 40 -base single-stranded synthetic oligonucleotide bFGF probe labeled with $\gamma-{ }^{32} \mathrm{P}$. The positions of the 7- and 3.7-kb bFGF-related mRNA, and 28S ribosomal RNA are as indicated. Shown below the Northern blots are the corresponding levels of $28 \mathrm{~S}$ rRNA.

\section{Results}

$m R N A$ hybridization with $b F G F c D N A$. Fig. 1 shows autoradiograms of agarose gels displaying hybridization of total RNA from preadipocytes using a human $\mathrm{bFGF}$ CDNA probe. The main hybridizing species were 7 and $3.7 \mathrm{~kb}$ in size.

Considerable variation in mRNA levels related to bFGF occurred between preadipocytes from different subjects (Fig. 1). In addition, preadipocytes from massively obese subjects 1 , $2,5,6,7,8$, and 9 had appreciably higher levels of mRNA related to bFGF than did preadipocytes from seven lean persons.

Fig. 2 shows the levels of mRNA related to bFGF expressed relative to ribosomal 28S RNA. Again, the values for preadipocytes from massively obese subjects $1,2,5,6,7,8$, and 9 were considerably higher than those for analogous mRNA from seven lean subjects.

Comparison of the mean level of mRNA related to bFGF for all preadipocytes from all lean subjects with that for all

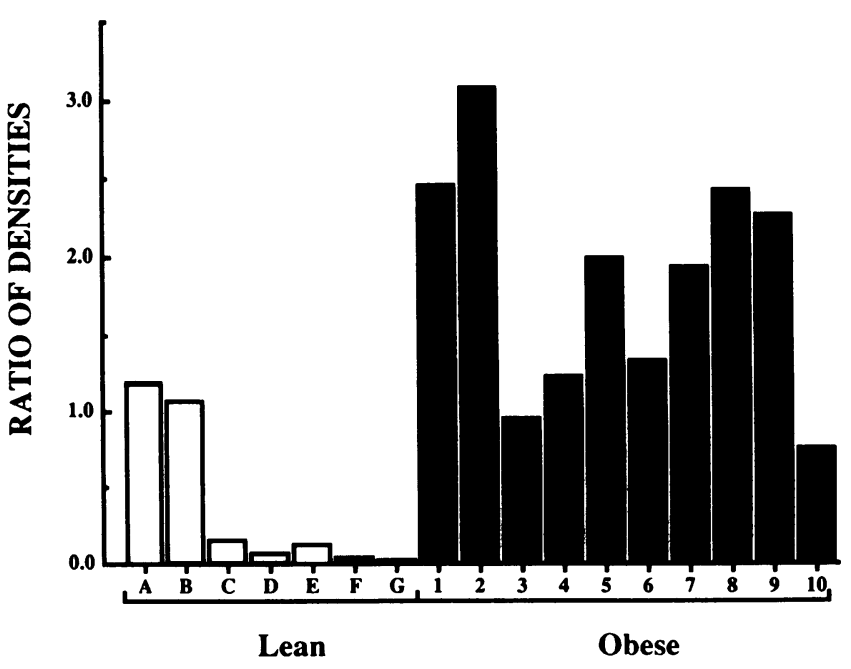

Figure 2. Densitometric analysis of 7-kb bFGF-related mRNA from Northern blots. The levels of the bFGF-related mRNA were standardized with the quantity of $28 \mathrm{~S}$ rRNA shown in Fig. 1. massively obese persons indicated a significantly higher value for the obese at $P<0.001$. As shown in Fig. 3, moreover, regression analysis indicates a moderate correlation $(r=0.71)$ between the levels of mRNA related to bFGF and degree of adiposity, expressed as BMI.

Fig. 4 illustrates that mitogenic factors contained in the conditioned medium bind to heparin and are eluted at a similar salt concentration as bFGF. Fig. 5 shows corresponding Western blots and SDS-electropherograms. The $\sim 66-\mathrm{kD}$ protein reacted with (1-24)bFGF antibodies, but not against antibodies directed against residues $40-63$ of bFGF, whereas the $\sim 32$-kD protein revealed the reverse immunoreactivity. Expectedly recombinant bFGF, $M_{\mathrm{r}} \sim 18 \mathrm{kD}$, reacted with both types of antibodies (data not shown). Regression analysis of the levels of the $\sim 66-\mathrm{kD}$ protein and degree of adiposity, as expressed by BMI, indicated a similar correlation $(r=0.72)$ to that displayed by the mRNA (Fig. 6).

Congruent with previous findings $(5,9)$, mature adipocytes freshly isolated directly from omental fat tissue revealed bFGF-

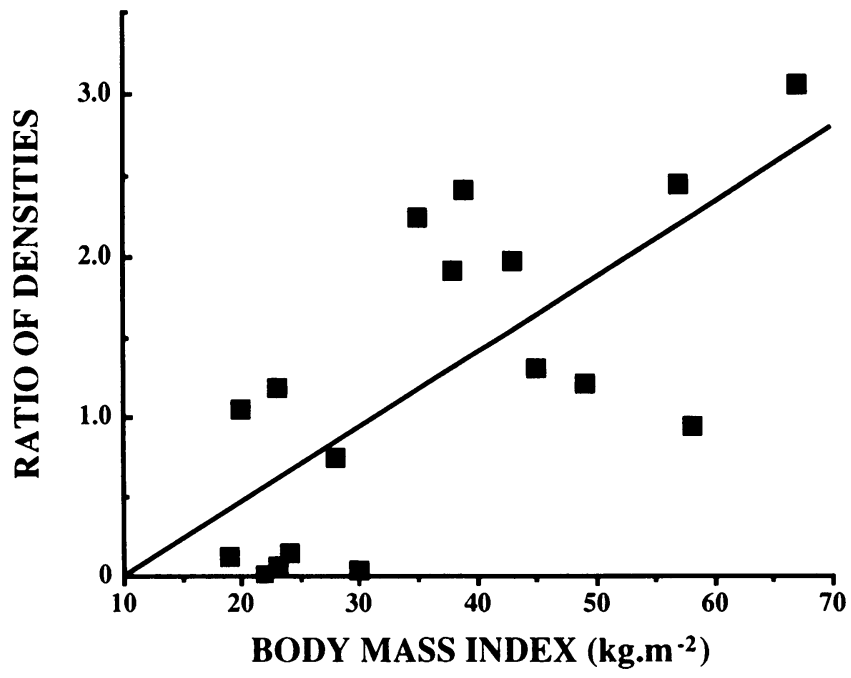

Figure 3. Correlation between bFGF-related mRNA expression and BMI. There is a positive correlation between BMI and bFGF-related mRNA expression $(r=0.71)$. 

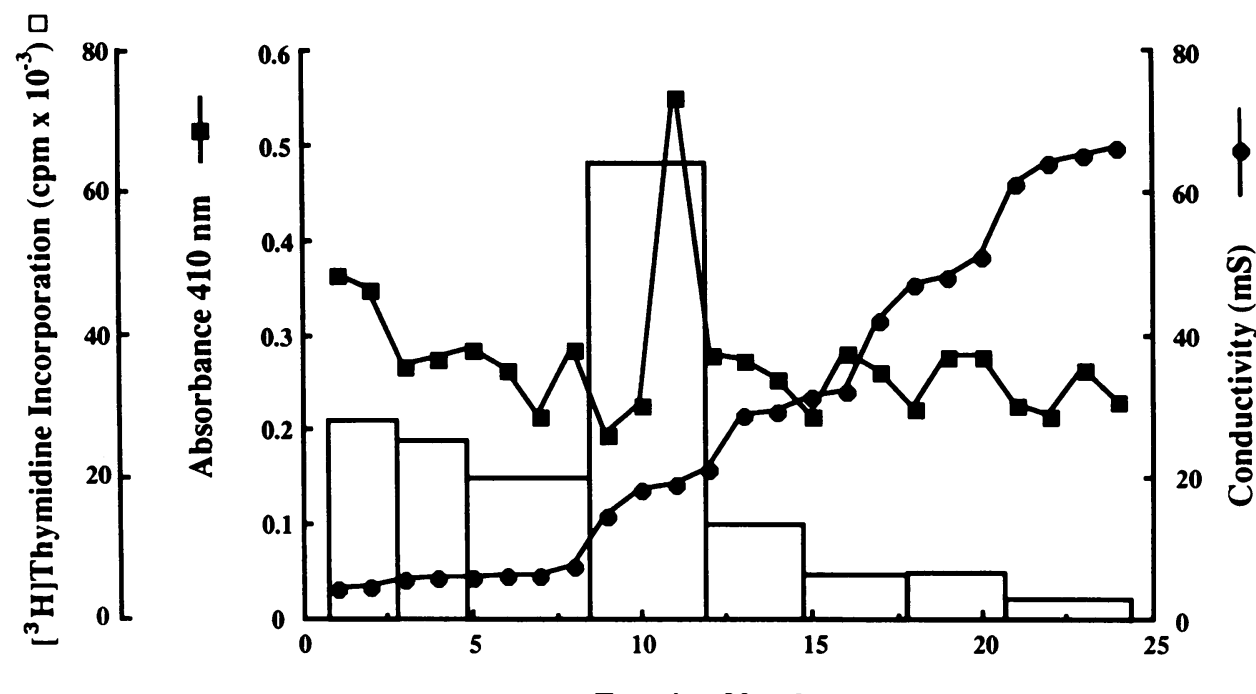

Figure 4. Mitogenic activity in fractions of conditioned medium from cultured preadipocytes of massively obese persons eluted from heparin-agarose. Concentrated conditioned medium was applied to a $\sim 1 \mathrm{ml}$ column equilibrated with 10 mM sodium phosphate buffer $(\mathrm{pH}$ 7.4) containing $0.15 \mathrm{M} \mathrm{NaCl}$. The column was washed with the same solution, and then eluted with the buffer containing sequentially: 0.6 $\mathrm{M} \mathrm{NaCl}, 1.1 \mathrm{M} \mathrm{NaCl}, 2.0 \mathrm{M} \mathrm{NaCl}$, and $3.0 \mathrm{M} \mathrm{NaCl}(\bullet)$ at a flow rate of $10-20 \mathrm{ml} / \mathrm{h}$. Fractions $(0.5 \mathrm{ml})$ containing bFGF-related proteins were detected by ELISA ( $\square$ ) with anti-(40-63)bFGF antibodies. Stimulation of replication by concentrated pooled fractions (open bars) was quantified by incorporation of $\left[{ }^{3} \mathrm{H}\right]$ thymidine into DNA of rat perirenal preadipocytes. The results are representative of four experiments. related mRNA expression at a low degree. To address the possibility that bFGF-related mRNA expression was related to the culture conditions, Northern blots were carried out with mRNA from whole (undigested) adipose tissue resected at surgery. As shown in Fig. 7, the expression was intermediate between that in cultured preadipocytes and the level of in mature fat cells, suggesting that preadipocytes also express bFGF-related DNA in vivo.

Fig. 8 indicates that preadipocytes isolated from both massively obese and noncorpulent persons had very similar dose responses to recombinant human bFGF.

\section{Discussion}

The expression of a gene(s) encoding a protein related to bFGF in adipose cells is consistent with the production of heparin- binding (fibroblast) growth factors in numerous tissues (4, 5 , 20 ). The size of the mRNAs hybridizing with the cDNA probe for human bFGF, 7.0 and $3.7 \mathrm{~kb}$, as well as minor transcripts of $3.5,2.8$, and $2.2 \mathrm{~kb}$, are analogous to that described for other human cells (21). The $M_{\mathrm{r}} \sim 66 \mathrm{kD}$ of the mitogenic protein identified by Western blotting is similar to the size of a major species found in a variety of tissues $(22,23)$, including the protein we isolated from bovine adenohypophyses, which stimulates the replication of preadipocytes (7). The lower molecular mass $\left(M_{\mathrm{r}} \sim 32 \mathrm{kD}\right)$ of the other mitogenic protein identified by the anti-(40-63)bFGF antibodies is similar to that of the oncogene products identified as belonging to the HBGF family (24).

Dimerization and/or quadrimerization of the classic 18$\mathrm{kD}$ protein could account for the presence of the higher molecular mass proteins. Yet, this possibility was discounted as the

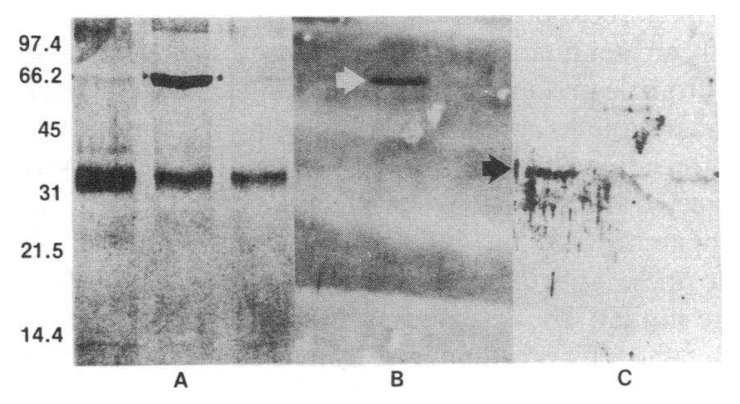

Figure 5. bFGF-related immunoreactive polypeptides in conditioned medium eluted from heparin-agarose. Conditioned-medium fractions eluted with $\sim 1.5 \mathrm{M} \mathrm{NaCl}$ were concentrated and were run on $12.5 \%$ SDS polyacrylamide electrophoresis gels and either silver stained transferred to nitrocellulose for Western analyses. $(A)$ Silver stain of eluted proteins. $(B) 66 \mathrm{kD}$ anti-(1-24)bFGF immunoreactive protein (open arrow). (C) 32-kD anti-(40-63)bFGF immunoreactive protein (solid arrow). Molecular mass standard positions are indicated. The results are representative of three experiments.

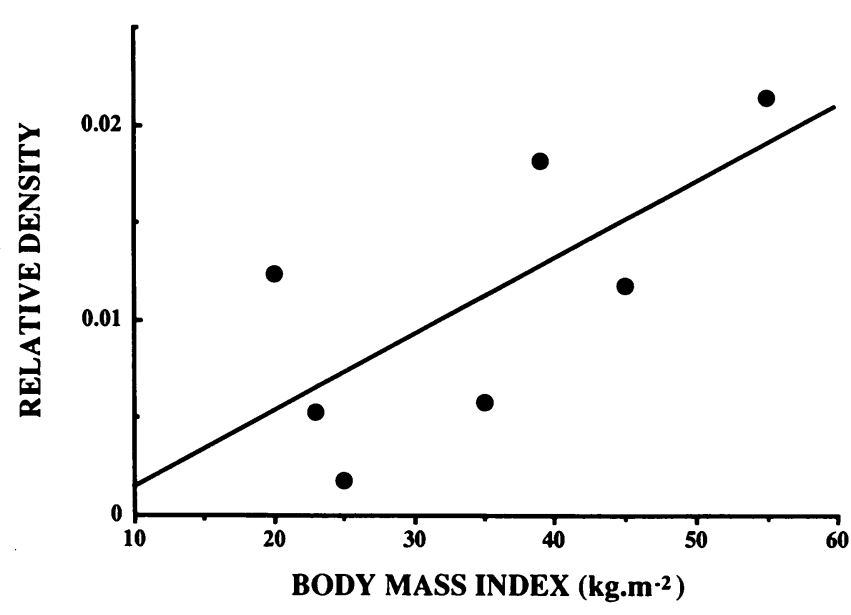

Figure 6. Correlation between bFGF-related protein in conditioned media and BMI. The relative quantity of the $66-\mathrm{kD}$ protein per cell bears a positive correlation $(r=0.72)$ with BMI. 


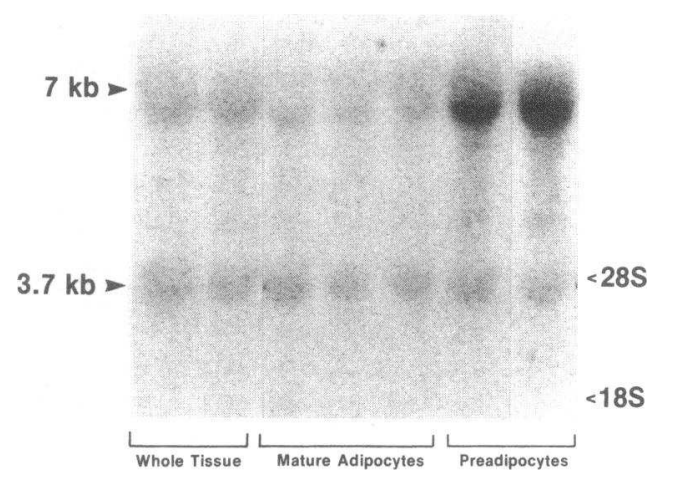

Figure 7. Northern blot analysis of RNA derived from omental adipose tissue, mature adipocytes, and preadipocytes. Total RNA (40 $\mu \mathrm{g}$ per lane) was hybridized with a 40 -base single-stranded synthetic oligonucleotide bFGF probe labeled with $\gamma-{ }^{32} \mathrm{P}$. The positions of the 7- and 3.7-kb bFGF-related mRNA, and 28S ribosomal RNA are as indicated.

samples were treated with SDS and sulfhydryl-reducing agents, and hence the identified proteins do not consist of subunits bound by noncovalent bonds or by disulfide linkages. In addition, in all of the conditioned media examined, immunoreactivity was not identified below the $\sim 32-\mathrm{kD}$ molecular mass protein. It is possible, however, that our compounds are made up of a smaller mitogenic protein ( $\mathrm{s}$ ) bound covalently to a carrier and/or a protease, as is the case for the nerve growth factor complex (25). Cleavage of the mitogenic component would then lead to a biologically active factor. There are several possibilities for the fact that two different antibodies against 18-kD bFGF react with only one or the other protein described in this manuscript. These include antigenically unique sequences, as well as different secondary and tertiary structure exposing or masking specific epitopes. Heparin-agarose chromatography also characterized the proteins as belonging to the heparin-

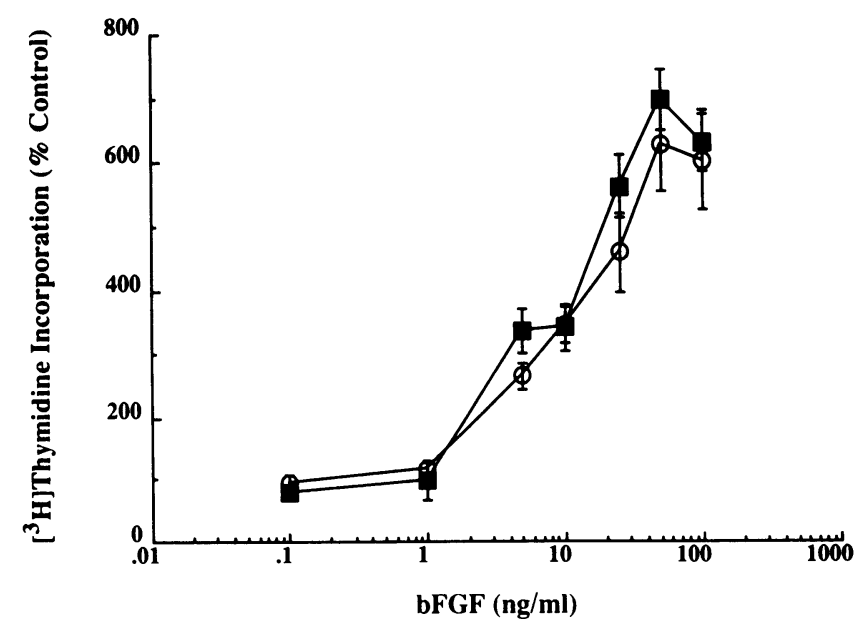

Figure 8. Dose responses of preadipocytes from massively obese and non-corpulent subjects to recombinant human bFGF. Stimulation of replication by bFGF $(0.1-100 \mathrm{ng} / \mathrm{ml})$ was quantified by incorporation of $\left[{ }^{3} \mathrm{H}\right]$ thymidine into DNA of preadipocytes. The results are expressed as percent increase above control (mean \pm SE) for three massively obese ( $\square$ ) and three noncorpulent (O) subjects. There was no significant difference. binding growth factor family, but more closely related to bFGF than to acidic FGF in that the proteins were eluted at higher salt concentrations.

In addition to inducing mesoderm development in the embryo, bFGF undoubtedly plays a fundamental role in tissue development and maintenance through its mitogenic influence on mesenchymal cells and through its angiogenic function (26). Relatedly, bFGF-related proteins, which are actually produced by both adipose and endothelial cells, would be expected to play an important role in the interactions between these cell types, intercellular communication critical for the development, structure, and function of fat tissue $(1,27,28)$. The widespread distribution of heparin-binding growth factors indicates that they function through paracrine/autocrine mechanisms. Congruent with the distinctive specialization of fat tissue, i.e., adipose differentiation and triglyceride accretion, bFGF has a pertinent, special effect, namely, inhibition of preadipocyte differentiation (9). Thus, as we have previously proposed, bFGF, and/or related proteins, are important for the development and maintenance of relatively undifferentiated, replicative preadipocyte pools (9). The finding that the expression of the heparin-binding growth factor ( $s$ ) is decreased appreciably during adipose differentiation, is consonant with its proposed function to expand and maintain adipose cells in a relatively undifferentiated state. Specific nutritional, endocrine, or cell-specific factors lead to differentiation, a process associated with decreasing quantities of FGF-like proteins, as demonstrated in this study.

bFGF, acidic FGF, and related higher molecular mass heparin-binding growth factors are produced in skeletal myocytes, particularly the proliferative satellite cells, both in vivo and in culture (29). Moreover, bFGF inhibits differentiation of myoblasts (30). Thus, in analogy to the proposal for the adipose cell system, bFGF and related proteins probably play an important role in maintaining pools of potentially replicative myocyte precursors. Then, through their mitogenic and angiogenic properties, these factors would mediate such functions as skeletal muscle contraction and regeneration (31). Similar considerations apply for the heparin-binding growth factors expressed in cardiac atrium and ventricle myocytes, although replication of ventricular cells is particularly limited $(32,33)$.

We have previously reported that omental preadipocytes from massively obese persons release into the culture medium significantly greater quantities of mitogenic proteins than preadipocytes from lean subjects (16). As shown in this paper, bFGF-related proteins are the major mitogenic compounds released by preadipocytes from both the lean and massively obese subjects. The augmented production by cells from the obese is apparently not due to decreased sensitivity or responsiveness to these growth factors since the dose responses to bFGF were similar. The excessive production of heparin-binding growth factors by preadipocytes from massively obese persons may have an amplifying effect resulting in accelerated development of hypercellularity. It is known that these factors are bound to extracellular matrix (34). We propose that increasing quantities of FGF-related proteins would be bound to the enlarging extracellular matrix, enabling recruitment of mitogenic factors from the expanding reservoir.

We thus propose that the augmented production of heparin-binding growth factors by preadipocytes from massively corpulent persons play an important role in the previously re- 
ported excessive replication of these cells $(2,11)$. Although it remains to be established, it is possible that the expression of bFGF-related proteins, which inhibit differentiation, is suppressed earlier or to a greater extent during differentiation of preadipocytes from the massively obese. In any case, it is known that their preadipocytes have an inordinate propensity to differentiation $(12,35)$. Such facilitated differentiation, coupled to excessive proliferation, would culminate in the hyperplasia of mature fat cells characteristic of massive obesity $(1,2,28)$.

\section{Acknowledgments}

The authors thank Joanne Forden for her technical assistance.

This research was supported by grant MT- 8460 of the Medical Research Council of Canada, and a grant from the Heart and Stroke Foundation of Canada (Ontario).

\section{References}

1. Roncari, D. A. K., and A. Angel. 1989. The fat cell. In Surgery for the Morbidly Obese Patient. M. Deitel, editor. Lea \& Febiger, Philadelphia. 3-18.

2. Roncari, D. A. K. 1990. Abnormalities of adipose cells in massive obesity. Int. J. Obes. 14(Suppl. 3):187-192.

3. Lau, D. C. W., G. Shillabeer, K. Wong, S. C. Tough, and J. C. Russell. 1990. Influence of paracrine factors on preadipocyte replication and differentiation. Int. J. Obes. 14(Suppl. 3):193-201.

4. Burgess, W. H., and T. Maciag. 1989. The heparin-binding (fibroblast) growth factor family of proteins. Annu. Rev. Biochem. 58:575-606.

5. Rifkin, D. B., and D. Moscatelli. 1989. Recent developments in the cell biology of basic fibroblast growth factor. J. Cell Biol. 109:1-6.

6. Roncari, D. A. K. 1981. Hormonal influences on the replication and maturation of adipocyte precursors. Int. J. Obes. 5:547-552.

7. Lau, D. C. W., D. A. K. Roncari, D. K. Yip, S. Kindler, and S. G. E. Nilsen. 1983. Purification of a pituitary polypeptide that stimulates the replication of adipocyte precursors in culture. FEBS (Fed. Eur. Biochem. Soc.) Lett. 153:395398.

8. Narve, M., and G. M. Ringold. 1988. A growth factor-repressible gene associated with protein kinase $\mathrm{C}$-mediated inhibition of adipocyte differentiation. J. Cell Biol. 107:279-286.

9. Roncari, D. A. K., and P. E. Le Blanc. 1990. Inhibition of rat perirenal preadipocyte differentiation. Biochem. Cell Biol. 68:238-242.

10. Liu, L., and C. S. Nicoll. 1988. Evidence for a role of basic fibroblast growth factor in rat embryonic growth and differentiation. Endocrinology. 123:2027-2031.

11. Roncari, D. A. K., D. C. W. Lau, and S. Kindler. 1981. Exaggerated replication in culture of adipocyte precursors from massively obese persons. Metab. Clin. Exp. 30:425-427.

12. Roncari, D. A. K., D. C. W. Lau, P. Djian, S. Kindler, and D. K. Yip. 1983. Culture and cloning of adipocyte precursors from lean and obese subjects: effects of growth factors. In The Adipocyte and Obesity: Cellular and Molecular Mechanisms. A. Angel, C. H. Hollenberg, and D. A. K. Roncari, editors. Raven Press, New York. 65-73.

13. Roncari, D. A. K., S. Kindler, and C. H. Hollenberg. 1986. Excessive proliferation in culture of reverted adipocytes from massively obese persons. Metab. Clin. Exp. 35:1-4.

14. Van, R. L. R., C. E. Bayliss, and D. A. K. Roncari. 1976. Cytological and enzymological characterization of adult human adipocyte precursors in culture. J. Clin. Invest. 58:699-704.

15. Van, R. L. R., and D. A. K. Roncari. 1977. Isolation of fat cell precursors from adult rat adipose tissue. Cell Tissue Res. 181:197-203.

16. Lau, D. C. W., D. A. K. Roncari, and C. H. Hollenberg. 1987. Release of mitogenic factors by cultured preadipocytes from massively obese human subjects. J. Clin. Invest. 79:632-636.

17. Bradford, M. M. 1976. A rapid and sensitive method for the quantification of microgram quantities of protein utilizing the principle of protein-dye binding. Anal. Biochem. 72:248-254.

18. Laemmli, U. K. 1970. Cleavage of structural proteins during assembly of the head of the bacteriophage T4. Nature (Lond.). 227:680-685.

19. Chomczynski, P., and N. Sacchi. 1987. Single-step method of RNA isolation by acid guanidinium thiocyanate-phenol-chloroform extraction. Anal. Biochem. 162:156-159.

20. Moscatelli, D., M. Presta, J. Joseph-Silverstein, and D. B. Rifkin. 1986. Both normal and tumour cells produce basic fibroblast growth factor. J. Cell. Physiol. 129:273-276.

21. Murphy, P. R., R. Sato, Y. Sato, and H. G. Friesen. 1988. Fibroblast growth factor messenger ribonucleic acid expression in a human astrocytoma cell line: regulation by serum and cell density. Mol. Endocrinol. 2:591-598.

22. Baird, A., F. Esch, P. Mormede, N. Ueno, N. Ling, P. Bohlen, S.-Y. Ying, W. B. Wehrenberg, and R. Guillemin. 1986. Molecular characterization of fibroblast growth factor: distribution and biological activities in various tissues. Rec Prog. Horm. Res. 42:143-205.

23. Riss, T. L., and D. A. Sirbasku. 1989. Characterization of polyclonal antibodies that distinguish acidic and basic fibroblast growth factors by using western immunoblotting and enzyme-linked immunosorbent assays. J. Cell. Physiol. 138:405-414.

24. Yayon, A., and M. Klagsbrun. 1990. Autocrine regulation of cell growth and transformation by basic fibroblast growth factor. Cancer Metastasis Rev. 9:191-202.

25. James, R., and R. A. Bradshaw. 1984. Polypeptide growth factors. Annu. Rev. Biochem. 53:253-292.

26. Folkman, J., and M. Klagsbrun. 1987. Angiogenic factors. Science (Wash. DC). 235:442-447.

27. Roncari, D. A. K. 1984. Pre-adipose cell replication and differentiation. Trends Biochem. Sci. 9:486-489.

28. Roncari, D. A. K. 1986. Obesity and lipid metabolism. In Clinical Medicine. J. A. Spittell and R. Volpé, editors. Harper \& Row, Philadelphia. 1-57.

29. Morrow, N. G., W. E. Kraus, J. W. Moore, R. S. Williams, and J. L. Swain. 1990. Increased expression of fibroblast growth factors in a rabbit skeletal muscle model of exercise conditioning. J. Clin. Invest. 85:1816-1820.

30. Spizz, G., D. Roman, A. Strauss, and E. N. Olson. 1986. Serum and fibroblast growth factor inhibit myogenic differentiation through a mechanism dependent on protein synthesis and independent of cell proliferation. J. Biol. Chem. 261:9483-9488.

31. Lindner, V., R. A. Majack, and M. A. Reidy. 1990. Basic fibroblast growth factor stimulates endothelial regrowth and proliferation in denuded arteries. $J$. Clin. Invest. 85:2004-2008.

32. Kardami, E., and R. R. Fandrich. 1989. Basic fibroblast growth factor in atria and ventricles of the vertebrate heart. J. Cell Biol. 109:1865-1875.

33. Casscells, W., E. Speir, J. Sasse, M. Klagsbrun, P. Allen, M. Lee, B. Calvo, M. Chiba, L. Haggroth, J. Folkman, et al. 1990. Isolation, characterization, and localization of heparin-binding growth factors in the heart. J. Clin. Invest. 85:433-441.

34. Baird, A., and N. Ling. 1987. Fibroblast growth factors are present in the extracellular matrix produced by endothelial cells in vitro: Implications for a role of heparinase-like enzymes in the neovascular response. Biochem. Biophys. Res. Commun. 142:428-435.

35. Le Blanc, P. E., D. A. K. Roncari, D. I. Hoar, and A. Adachi. 1988. Exaggerated triglyceride accretion in human preadipocyte-murine renal line hybrids composed of cells from massively obese subjects. J. Clin. Invest. 81:16391645 . 